\title{
PRESENT VALUE OF IMMATURE STANDS
}

\section{By J. B. MILLAR ${ }^{1}$}

In the following paper I propose to deal with some of the general factors arising from the consideration of the subject of valuation of immature timber stands, and to outline the practices which we have developed to meet the actual needs of our company's operations. The reader will find here no discussion of the mensurational problems involved, and no contribution to the theory of forest valuation.

There are two points which I would like to stress:

1. Young stands are valuable.

2. There are many ways of calculating present worth.

I believe that in Ontario there is not yet full realization of the potential that exists in immature stands. The American conception of value is a reflection of the development of the country. Having matured, as a nation, faster than Canada, the United States has developed its natural resources to a greater degree, particularly its forest economy. As a result all regions, except portions of the Pacific Northwest, are dependent on second-growth stands, and through necessity we have been forced to appreciate their truth worth. A specific example of a common Canadian attitude is found in the valuation statistics of forest fire reports. The class of timber destroyed is always listed, usually giving acres of virgin timber, the volume of merchantable material and its cash value. Down near the bottom of the report will be acres of secondgrowth or acres of young stands listed as "no value." For black spruce, at least a fire in a young stand will set back the succession two rotations. Expressed differently, one can say that for a long-term estimate, a burned secondgrowth stand will represent a bigger cash loss to the country than a burned overmature forest.

The problem in evaluating immature stands is to determine the present net worth of the young trees already established. In our own case it has been necessary to calculate the price that could be paid for the purchase of fee lands, and in a few instances, a reasonable valuation for the sale of the same. Canadian industrial foresters are going to meet this problem more often in the future and experience in the Lake States may have have some application to Canadian conditions.

The scope of the problem can be narrowed down by eliminating mature stands and bare land. Present cruising methods will provide volume figures for merchantable stands. Current stumpage prices can be determined from any number of sources, such as public auctions, bids on government or private timber. If necessary, by deducting operating expenses from current market prices, a reasonable estimate for stumpage can be obtained. Hence by combining volume and value per unit, a present worth figure is developed. On a similar basis, bare land value must be governed by purchase or sale of comparable areas, that is supply and demand will set the price. In this case, minor adjustments should be made for accessibility and the intrinsic growth capacity of the land. The calculation, however, is relatively simple.

I Chief of Staff; Woodlands Department, Kimberly Clark Corporation, Neenah, Wisconsin, U.S.A. 
The toughest problem is in evaluating the immature stands, rarely fully stocked and often made up of a number of species. The species will undoubtedly differ in tolerance, in rotation length, and in ultimate conversion value. One possible method is to compare the natural stand with smiliar planted areas. The basic cost of establishing the plantation, protecting it and bringing it up to the present can be used only if the natural stand is well-stocked and quite young. The longer the period involved, the more difficult becomes this method, and in actual practice, we have yet to find a case that can be treated in this manner. The alternative, of course, is to start with an estimate of the final products to be obtained and discount their value back to the present. An analysis of some of the methods which have proved successful will illustrate the factors that must be considered. It should be emphasized that no single method will be satisfactory for all conditions and each organization will have to develop its own method to suit its own particular requirements.

I would like to refer you to a system developed by the Nekoosa-Edwards Paper Company of Wisconsin in conjunction with the Lake States Forest Experiment Station. It has been written up in the Journal of Forestry, September, 1948, so I will only give you a bare outline of the factors which they consider. They use a basic or standard price per cord, the price varying with each species. This basic figure is adjusted for accessibility to fire protection, for its relation to the center of consumption, either by length of truck haul or railroad freight rates, and finally through the amount of new road construction required to operate the timber. From this they arrive at a stumpage price for a particular tract of wood. They add, if necessary, a marginal allowance to desirable stands; the allowance being governed by the urgency of the company's need for wood and the advantages of consolidating ownership with previous purchases. Finally it is possible to make a further allowance for quality of wood within a single species.

I want to keep this discussion as simple as possible but I think some of the detail from a specific example will help. First, for any sample area, it is necessary to determine the species present, the average age and height and hence site quality, the stocking group based on stems per fifth acre plot, the waiting period to maturity, the location away from the mill, the haul to railroad, and the road construction required. The expected gross yield is determined from site quality, plus the waiting period in years. This gross yield is reduced for fire or insect risk according to its relative value as compared with a standard. Thus we get an expected net yield which can be converted into expected net income. The recurring costs such as taxes, administration, overhead and protection charges are compounded and deducted from the net income. The resultant figure is discounted back to the present and thus we obtain the present worth of net income.

Since it is expected that when the stand matures, the company will urgently need wood, a marginal allowance is calculated by formula. It is not all clear profit because from it must be subtracted any extra hauling cost adjustments, if present, including adjusted freight rates, haul to railroad and road construction. The differential is discounted and added to present worth of net 
income' to give the maximum present value of the immature timber. Merchantable timber value and land value, if any, are added to give present worth per acre for the tract.

To be technically correct, the future purchasing value of the dollar should be estimated and the final figure adjusted accordingly. Based on long-term historical trends, the purchasing value will continue to decline in the future but how to make an accurate estimate seems to be more in the field of the economist than the forester.

The Nekoosa-Edwards' method seems to cover all possible phases of the problem. The chief objection to it is the difficulty of obtaining all the basic data required. In other words, for many situations it is too involved, particularly for large tracts more or less inaccessible at present and where future operations have not yet reached the planning stage. In northern Minnesota, the North Star Timber Company has developed a somewhat simpler program based primarily on the use of aerial photographs and the per cent of crown closure as determined from the pictures. A series of tables has been produced which give the present value of advance growth per acre in dollars. The basic information was obtained from, "Forest Types and Condition Classes in the Lake States", issued June 4, 1948, by the Lake States Forest Experiment Station. Where species are similar, such as poplar and white birch, one set of tables is used for the combined species. A series of tables is made for each site class, within the species. The factors considered in each table are per cent of crown closure and present d.b.h.; the latter is subsequently expressed as number of years to reach 6-inch average d.b.h. A separate table correlates number of stems per acre and crown closure and is used when the area is mapped from the ground rather than from photographs. With this method, $21 / 2 \%$ compound interest is used as in the previous one for discounting net returns. Taxes and administration are estimated to be $25 \mathrm{c}$ per acre annually rather than $30 \mathrm{c}$ as in the previous example and the annual charges are not compounded in this case but absorbed each year against operations. This is not correct according to forest finance textbooks but it is the way the company's accounting system works.

In recent years some of the pulpwood companies in Upper Michigan have modified their cruising methods to permit relatively accurate, short-term estimates of future growth. Tally is extended down below merchantable-sized trees to include reproduction and saplings but not all trees are tallied. In a clump of saplings, only one or two dominants are selected; if a tree is badly suppressed, diseased or very crooked, it is completely eliminated. In other words, allowance for mortality is made by the timber estimator at the time of cruising. By borings, the number of rings in the last inch of growth are obtained for all diameter classes and species. Combining these, we can get a growth prediction and estimated yield ten or fifteen years ahead. Twenty years seems to be the outside limit for such a system which is one disadvantage. Another is the likelihood of error since much depends on the experience and judgment of the estimator. Admittedly, permanent sample plots and accurate mortality figures would be better but this simplified system has given some very good results for a short period estimate. 
Carrying this innovation in cruising over into land evaluation, the William Bonifas Lumber Company produced a series of tables based on rings per inch and stems per acre. In this case, trees under merchantable size were tallied in 2-inch diameter classes and were designated as 1-inch or 3-inch trees. To apply the valuation table, the 3 -inch trees are given double weight. Spruce and balsam are added together although the basic stumpage price varies for each species. The final figure varies with the proportion of spruce in the mixture. Generally the balsam grows faster than the spruce. For example, balsam growing five rings per inch will be found with spruce at six rings per inch and for our purpose they are combined in the same table.

A sample may make the procedure a little clearer. Using $\$ 2.50$ per cord for spruce and $\$ 1.50$ per cord for balsam, a stand of young timber that has 240 stems per acre and is half spruce and half balsam is now worth $\$ 15.50$ per acre, provided the spruce is growing at five rings per inch and balsam four. However, with the same stumpage prices, the same number per acre, the same proportion of species but with balsam at nine rings and spruce at eleven, then the current value is only $\$ 5.00$ per acre.

With these tables, we have used 30c per acre per year to cover taxes and administration costs. We also used 5\% simple interest. The reason for this is twofold. The period is usually short and compounding would not change the picture as much as when the prediction covers a longer time. Secondly, there is usually some larger and older trees in the stand-rarely is the stand even-aged. Thus there is some wood now merchantable or nearly so which will be harvested in the near future. The returns from this will offset carrying charges now being incurred. Again this is not according to the theorists but fits in with our business practices.

One further reduction is made in the value of young timber if merchantable trees are present. It is maintained that when the mature trees are cut, some of the reproduction will be damaged regardless of how careful the cutters may be. If the mature trees are not cut, they will retard the growth of the smaller trees to some extent. Therefore the future value of 1 -inch and 3-inch trees is reduced proportionately according to present cords per acre. For example, if there are 3 cords per acre present, the value of the small trees is reduced by one-third, and if there are 5 cords, then the reduction is one-half.

Summarizing, it is unlikely that any of the three systems outlined above will apply exactly to any specific area in Ontario. That is, any organization considering young stand values must necessarily work out its own method to suit circumstances. However, the factors herein mentioned may serve as a guide to reaching a solution to this problem. 